\title{
Sport Performance Structure in Female Pole Vault from the Point of View of Physical Activity Kinematic Parameters
}

\author{
Struktura sportovního výkonu ve skoku o tyči žen z pohledu \\ kinematických parametrů fyzické aktivity
}

\author{
Peter Krška, Jaromír Sedláček \\ Faculty of Education, Catholic University, Ruzomberok, Slovakia
}

\begin{abstract}
This research is oriented at explanation of sport performance by angle, speed, time and space characteristics of centre of gravity, positions of body, extremities and pole during approach, take-off and jump realization in female pole vault. Kinematic parameters were gained by two-dimension analyser Consport Motion Analysis System (CMAS). There are involved 19 female pole vault jumpers with sport performance 408.1-490.5 cm (average result $431.2 \mathrm{~cm}$ ). From the point of biomechanical movement activity analyse we consider as a more objective performance criterion (dependent variable) maximal centre of gravity height that were reached at valid attempts by female pole vault jumpers. By twodimension (2-D) analyse of group of female pole vault jumpers there were revealed 76 independent variables that entered into process of multiple correlation and regression analysis.

On $1^{\text {st }}$ sport structure performance factor level we isolated two complex parameters absolute grip and standing over by which we can explain dependent variable maximal centre of gravity height on $100 \%$. With stated proceeding we could separate seven factors on $2^{\text {nd }}$ level. Three of the parameters horizontal speed of centre of gravity at moment of take-offend, centre of gravity height at moment of take-off end and operating angle during take-off are bound with explanation of absolute grip variable. Four others parameters vertical speed of centre of gravity at the end of pull with turn, centre of gravity height at moment of end of lifting, time duration of take-off and climb angle explain standing over. 14 more factors are found on $3^{\text {rd }}$ sport structure performance level. Thus we succeeded in this process to reduce number of decisive variables with their mutual relationships and hierarchy.

Transparent and simplified model of female pole vault sport performance structure enables to coaches and jumpers improve technical training.
\end{abstract}

\begin{abstract}
Abstrakt
Tento výzkum je zaměřen na vysvětlení sportovního výkonu z hlediska úhlu, rychlosti, časové a prostorové charakteristiky těžiště, polohy těla, končetin a tyče při přibližení, vzletu a realizaci skoku o tyči žen. Kinematické parametry byly získány dvourozměrným analyzátorem Consport Motion Analysis System (CMAS). Bylo zahrnuto 19 juniorek, skokanek o tyči, se sportovním výkonem 408,1-490,5 cm (průmèrný výsledek 431,2cm). Z hlediska analýzy biomechanické pohybové aktivity považujeme za objektivnějši výkonnostní kritérium (závislou proměnnou) maximální výšku těžiště, které bylo dosaženo při platných pokusech prí skoku o tyči. Dvojrozměrnou (2-D) analýzou skupiny skokanek o tyči se zjistilo 76 nezávislých proměnných, které vstoupily do procesu multikorelační a regresní analýzy.

Na úrovni prvního výkonnostního faktoru sportovní struktury jsme izolovali dva komplexní parametry: absolutní úchop a zvrat, čímž dokážeme vysvětlit závislou proměnnou maximální výšku těžiště na 100\%. S uvedeným postupem jsme mohli na 2. úrovni oddělit sedm faktorů. Trí z parametrů horizontální rychlosti těžiště v okamžiku odletu, výška těžiště v okamžiku odletu a pracovní úhel prí vzletu jsou vysvětlením absolutní proměnné úchopu. Další čtyři parametry vertikální rychlosti těžiště na konci tahu s otočením, výška těžiště v okamžiku ukončení zdvihu, doba trvání vzletu a úhel stoupání vysvětlují zvrat. Na úrovni 3. úrovně sportovní struktury je nalezeno dalších 14 faktorů. Tím se nám podařilo v tomto procesu snízit počet rozhodujících proměnných s jejich vzájemnými vztahy a hierarchií.
\end{abstract}


Transparentní a zjednodušený model struktury sportovních výkonů ve skoku o tyči žen umožňuje trenérům a skokanům zlepšit technický trénink.

Keywords: female pole vault, kinematic parameters, sport performance structure.

Klíčová slova: skok o tyči žen, kinematické parametry, struktura sportovního výkonu.

\section{INTRODUCTION}

The development of models of kinematic substructures of the competitive movement activity of jumping athletic events is one of the research areas in athletics (Kostial - Bercel, 1996; Krska, 2001; Benko, 2001; Cihova - Kostial, 2004). Particularly sporting practice requires a careful analysis not only of competitive activity, but also to offer research in the field of technical preparation means of jumpers used in training conditions.

Long-term sports training must be based on knowledge of the structure of sport performance and its genesis, including model characteristics of body development, physical and sport performance and derived selection criteria for any sport preparation stage. One of the directions for optimizing the training load is also creation of the rational technique model and the determination of the biomechanical indicators of the movement activity of the female pole-vault jumpers, which condition the increase of the level of sport performance.

The kinematic analysis allows to identify the character of the movement activity, thus is created the premise for subsequent rationalization of movement. Lately, several authors have dealt with kinematic analysis in their works, for example, Brodani, 2002; Brodani - Vavak - Selinger, 2003; Gimunova - Kasovic - Zvonar - Turcinek - Matkovic - Ventruba - Vavacek - Knjaz, 2015; Grabner, 1997; Kostial - Dremmelova, 2001; Korvas - Zvonar - Musil - Senkyr - Kalina, 2013; Krska, 2001; Krška - Kostial, 2000; McGinnis, 1997).

Pole vault is the only athletic event in which the performance is reached with use of tool. The pole use put this event away from fundamental locomotion and adjoins it to complex athletic events. The movement activity is realised in two basic parts; the first is approach ended with take-off and the second there are the movement activities of jumper on the pole. The approach has cyclical movement structure and it is influenced both arms holding, bearing and displacing pole. The movement activity on the pole has on the contrary acyclic character and represent the structure of shifting movements in front and upside position at parallel rotation round horizontal and vertical body axes and round pole and that is performed at optimal time sequence - rhythm (Krska - Kostial - Sedlacek, 2014).

A good understanding of the mechanics of pole vaulting is fundamental to performance because this event is quite complex, with several factors occurring in sequence and/or in parallel. These factors mainly concern the velocities of the jumper-pole system, the kinetic and potential energy of the jumper and the strain energy stored in the pole, the force and torque applied by the athlete, and the pole design. Pole vault performance is basically influenced by the energy exchange between the jumper and pole. Ideally, as the athlete clears the crossbar, the jumper mechanical energy must be composed of high potential energy and low kinetic energy, guaranteeing the high vertical component of the vault (Frere at al., 2010).

For technique evaluation we need biomechanics analyse in order to evaluate more precisely technique of movements, enables to identify differences from ideal technique model and thus even form orientation its further improvement. At sportsmen technique evaluation we start from mechanic phenomena that are in biomechanics called biomechanical characteristics. These phenomena make sportsman movement technique more concrete in its kinetic and dynamic mani- 
festation and they can be measured and evaluated. The more complex movement activity is, the more needed and helpful can biomechanical analyse be. Kinematical analyse enables to learn movement activity character and thus is formed prerequisite for following movement rationalization and its contribution on training process improvement (Krska - Kostial - Sedlacek, 2014).

\section{OBJECTIVES}

In this contribution we want to reveal sport performance structure in female pole vault. It means to find relevant indicators and their mutual relations and hierarchy.

\section{MATERIAL AND METHODS}

This research was performed on the meetings Golden spiked shoes in Ostrava, Czech Republic. There are involved 19 female pole-vaulters with the sport performance $380-483 \mathrm{~cm}(\operatorname{tab} 1)$. Kinematic and dynamic parameters were gained by two-dimension analyser Consport Motion Analysis System (CMAS). Totally we were working with 76 parameters, which step by step were entering into multiple correlation and regression process. As a sport criterion (independent variable) was chosen the maximum height of the centre of gravity that has been achieved at successful and a valid competitive attempt.

Tab. 1: Statistical characteristic of kinetic parameters of the whole group, sport performance $380-483 \mathrm{~cm}$ $(n=19)$

\begin{tabular}{|l|l|c|r|r|r|c|}
\hline \multicolumn{2}{|l|}{ Parameter (u) } & [unit] & $\mathbf{x}$ & $\mathbf{x}_{\max }$ & $\mathbf{x}_{\min }$ & $\mathbf{S}$ \\
\hline$u 1$ & Maximal centre of gravity height & {$[\mathrm{cm}]$} & 448.03 & 490.50 & 408.10 & 23.07 \\
\hline$u 2$ & Absolute height of upper arm grip & {$[\mathrm{cm}]$} & 403.11 & 420.00 & 385.00 & 10.86 \\
\hline$u 3$ & Standing over (peak height) & {$[\mathrm{cm}]$} & 44.92 & 70.50 & 11.20 & 16.24 \\
\hline
\end{tabular}

\section{RESULTS AND DISCUSSION}

Sport performance structure in women's pole-vault from the point of view of physical activity kinematic indicators we are explaining on example of female jumpers with average sport performance level $431.2 \mathrm{~cm}$. From the point of motion activity biomechanical analysis, we consider as more objective performance criterion the maximum height of the centre of gravity that has been achieved at successful and a valid competitive attempt. These values are in the range of $408.1-490.5 \mathrm{~cm}$ for the monitored set of jumps.

We succeeded to reduce these initial 76 indicators on 24 and also to sort them into three levels of sport performance structure (tab 2). 
Tab 2: Selected speed, angle, time and centre of gravity parameters $(\mathrm{u})$ in sport performance structure levels

\begin{tabular}{|c|c|c|}
\hline \multicolumn{3}{|c|}{$1^{\text {st }}$ sport performance structure level } \\
\hline $\mathrm{u} 1$ & maximal centre of gravity height - criterion (dependent variable) & {$[\mathrm{cm}]$} \\
\hline $\mathrm{u} 2$ & absolute height of upper arm grip & {$[\mathrm{cm}]$} \\
\hline $\mathrm{u} 3$ & standing over (peak height) & {$[\mathrm{cm}]$} \\
\hline \multicolumn{3}{|c|}{$2^{\text {nd }}$ sport performance structure level } \\
\hline $\mathrm{u} 12$ & horizontal speed of centre of gravity at moment of end of take-off & {$\left[\mathrm{m} \cdot \mathrm{s}^{-1}\right]$} \\
\hline $\mathrm{u} 28$ & centre of gravity height at moment of end of take-off & {$[\mathrm{cm}]$} \\
\hline u54 & operating angle during take-off & {$\left[{ }^{0}\right]$} \\
\hline $\mathrm{u} 21$ & vertical speed of centre of gravity at the end of pull with turn & {$\left[\mathrm{m} \cdot \mathrm{s}^{-1}\right]$} \\
\hline u34 & centre of gravity height at moment of end of lifting & {$[\mathrm{cm}]$} \\
\hline $\mathrm{u} 43$ & time duration of take-off & {$[\mathrm{s}]$} \\
\hline $\mathrm{u} 55$ & climb angle & {$\left[{ }^{0}\right]$} \\
\hline \multicolumn{3}{|c|}{$3^{\text {rd }}$ sport performance structure level } \\
\hline $\mathrm{u} 11$ & horizontal speed of centre of gravity at moment of tread-down of take-off & {$\left[\mathrm{m} \cdot \mathrm{s}^{-1}\right]$} \\
\hline $\mathrm{u} 13$ & speed loss of centre of gravity during take-off & {$\left[\mathrm{m} \cdot \mathrm{s}^{-1}\right]$} \\
\hline u9 & character of take-off (vertical projection difference of upper arm grip) & {$[\mathrm{cm}]$} \\
\hline $\mathrm{u} 53$ & angle of take-off & {$\left[{ }^{0}\right]$} \\
\hline $\mathrm{u} 52$ & angle of tread-down of take-off & {$\left[{ }^{0}\right]$} \\
\hline u56 & angle between body and vertical line at moment of straightening up end & {$\left[{ }^{0}\right]$} \\
\hline $\mathrm{u} 71$ & moment of end of pull wit turn (time interval from take-off beginning) & [s] \\
\hline $\mathrm{u} 33$ & centre of gravity height at moment of end of pull with turn & {$[\mathrm{cm}]$} \\
\hline $\mathrm{u} 57$ & angle between body and vertical line at moment of pull with turn end & {$\left[{ }^{0}\right]$} \\
\hline $\mathrm{u} 7$ & angle of tread-down of take-off & {$\left[{ }^{0}\right]$} \\
\hline $\mathrm{u} 8$ & rate of last two steps of approach & {$[\mathrm{cm}]$} \\
\hline $\mathrm{u} 17$ & vertical speed of centre of gravity at the end of hanging position & {$\left[\mathrm{m} \cdot \mathrm{s}^{-1}\right]$} \\
\hline u29 & centre of gravity height at moment of end of hanging & {$[\mathrm{cm}]$} \\
\hline $\mathrm{u} 44$ & time duration of hanging & {$[\mathrm{s}]$} \\
\hline
\end{tabular}

The resulting maximum height of the centre of gravity can be explained by the $100 \%$ variability of absolute grip and standing over (fig 1). The absolute grip represents the distance of the upper hand grip from the bottom end of the bar, after deducting the depth of the take-off box $(20 \mathrm{~cm})$. Standing over is the difference between the maximum height of the centre of gravity and the absolute grip. We consider it an objective, indirect indicator of the technical readiness of the jumpers. The resulting maximum height is actually the sum of these both parameters.

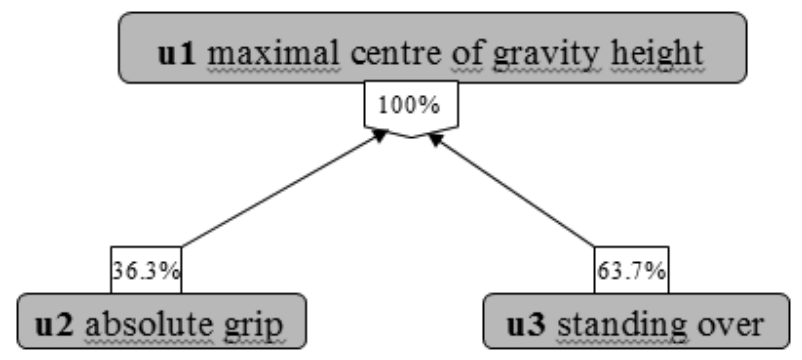

Fig. 1: Relations of limited parameters to dependant criterion ( $1^{\text {st }}$ factor level) 
Tab. 3: Calculation coefficients

\begin{tabular}{|c|c|c|c|c|}
\hline & $\begin{array}{l}\text { unstandardized } \\
\text { coefficients }\end{array}$ & $\begin{array}{l}\text { standardized } \\
\text { coefficients }\end{array}$ & correlations & \\
\hline & B & Beta & Zero-order & $\%$ \\
\hline absolute grip & 1.000 & 0.471 & 0.771 & 36.3 \\
\hline standing over & 1.000 & 0.704 & 0.905 & 63.7 \\
\hline \multicolumn{4}{|c|}{ dependent variable: centre of gravity maximal height (u1) } & $\overline{100.0}$ \\
\hline
\end{tabular}

The coefficients of partial determination ( $\operatorname{tab} 3$ ) in the standard shape give portions for explaining the total variation of the maximum height of the centre of gravity, namely $63.7 \%$ of the standing over and $36.3 \%$ of the absolute grip. The deliberate and computed inclusion of these indicators into the first factor level allowed us to divide the set of factors into two groups. The first is characterized by the approach activity and the second activity of the jumpers on the pole. We have entered multiple correlation analysis with predefined sets of factors that were arranged according to the time sequence in order any independent variables explain the dependent variable, which followed in the kinematic chain after the explanatory factors. We also considered the value of the paircorrelation coefficient, and the choice of factors was also affected with our training experience.

The height of the absolute grip in the jumpers ranged from 385 to $420 \mathrm{~cm}$. The $35 \mathrm{~cm}$ variation range was smaller than the sports performance $(103 \mathrm{~cm})$ and the maximal centre of gravity height $(82.4 \mathrm{~cm})$. For the $51.6 \%$ explanation of the variation of the absolute grip height, the score of the three independent variables is shared by the second factor level. Of these, the highest information rate has the horizontal velocity of the centre of gravity at the end of take-off (u12-35.1\%), followed by the centre of gravity at the end of take-off ( $\mathrm{u} 28-12.8 \%)$ and the calculated action (operating) angle (u54) with a $3.7 \%$ share (fig 2, tab 4).

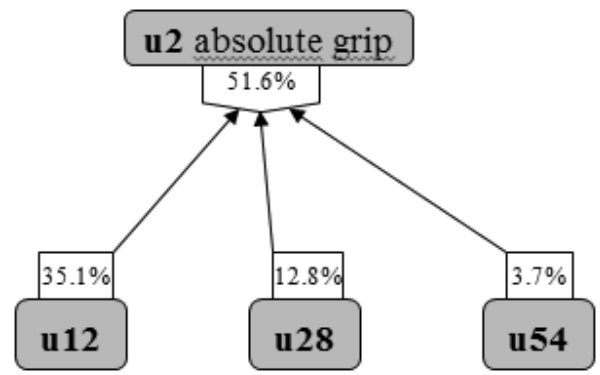

Fig. 2: Relations the $2^{\text {nd }}$ factor level parameters on absolute grip

Tab. 4: Calculation coefficients

\begin{tabular}{|l|c|c|c|c|}
\hline & $\begin{array}{c}\text { unstandardized } \\
\text { coefficients }\end{array}$ & $\begin{array}{c}\text { standardized } \\
\text { coefficients }\end{array}$ & correlations & \\
\hline & $\mathbf{B}$ & Beta & Zero-order & $\%$ \\
\hline VAR000012 & 9.599 & 0.590 & 0.595 & 35.1 \\
\hline VAR000028 & 0.7407 & 0.323 & 0.395 & 12.8 \\
\hline VAR000054 & -0.33 & -0.194 & -0.191 & 3.7 \\
\hline \multicolumn{4}{|l}{ dependent variable: absolute grip (u2) } & $\mathbf{5 1 . 6}$ \\
\hline
\end{tabular}


For the observed performance level, the optimal horizontal speed of the centre of gravity is reached at an average level of $6.46 \mathrm{~ms}^{-1}$ at which the jumpers perform a take-off with an action (operating) angle of $34.60^{\circ}$ at the centre of gravity height $97.1-117.1 \mathrm{~cm}$. The values of the centre of gravity overpass above the absolute grip height in our group range from average 11.2 to very good $70.5 \mathrm{~cm}$.

Multiple coefficient of determination confirms that $95.7 \%$ of the variance score of the standing over can be explained by score variation of the four indicators that were pushed to the second factor level (fig 3, tab 5). They characterize the activity of jumpers on pole - the vertical speed of the centre of gravity at the end of the pull with turn (u21), the centre of gravity height reached in the lifting (u34), the duration of take-off (u43) and the climb angle of the centre of gravity (u55).

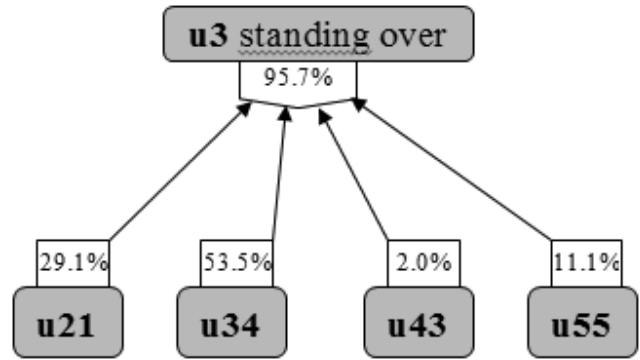

Fig. 3: Relations the $2^{\text {nd }}$ factor level parameters on standing over

Tab. 5: Calculation coefficients

\begin{tabular}{|l|c|c|c|c|}
\hline & $\begin{array}{c}\text { unstandardized } \\
\text { coefficients }\end{array}$ & $\begin{array}{c}\text { standardized } \\
\text { coefficients }\end{array}$ & correlations & \\
\hline & $\mathbf{B}$ & Beta & Zero-order & $\%$ \\
\hline VAR00034 & 0.452 & 0.593 & 0.903 & 53.5 \\
\hline VAR00021 & 8.617 & 0.378 & 0.770 & 29.1 \\
\hline VAR00043 & 201.925 & 0.247 & 0.081 & 2.0 \\
\hline VAR00055 & -0.980 & -0.199 & -0.558 & 11.1 \\
\hline \multicolumn{4}{|l|}{ dependent variable: standing over (u3) } \\
\hline
\end{tabular}

The highest part of the explanation is the height of the centre of gravity reached at the end of the phase lifting (u34) when our jumpers already at this stage reached in average of $99.5 \%$ of the total height of jump. Jumpers already have no gains in the centre of gravity during the final phase of the jump, which is the bar crossing. We suppose that our females do not use enough pole position energy as it is in case of male jumpers of a comparable performance level. We consider the fact to be a manifestation of the lack of their technical level preparation and the potential stimulus for searching ways to further performance improve. From our point of view, the most interesting indicator is the vertical velocity of the centre of gravity at the end of phase pull with turn (u21), which contributes to the explanation of the standing over by a partial influence of $29.1 \%$. In the group the vertical velocity values were at $1.33-4.51 \mathrm{~m} . \mathrm{s}^{-1}$. For this monitored group, the vertical velocity values moved at $1.33-4.51 \mathrm{~m} . \mathrm{s}^{-1}$. From movement activity angle characteristics is best enforced the climb angle (u55) with an impact ratio of $11 \%$. Its values range from $14.9^{\circ}$ to $27.0^{\circ}$. The last indicator contributing to the explanation of the standing over is the take-off duration (u43) with $2 \%$ partial effect with values ranging from 0.08 to $0.12 \mathrm{~s}$. 
The indicators that we can characterize like supporting are put into the third factor level. They are more elementary in character and influence sport performance through mediated links through higher levels factors.

In approach activity the $\mathrm{u} 12$ (horizontal speed of centre of gravity at moment of take-off end) is explained on $100 \%$ by the horizontal speed of the centre of gravity at take-off ( $u 11-14.6 \%$ ) and the loss of the horizontal velocity during take-off (u13-85.4\%); see part of fig 4 (relations $\mathrm{u} 12$ to $\mathrm{u} 11$ and $\mathrm{u} 13$ ). From the point of view of the watched performance and the achievement of the required centre of gravity horizontal velocity of the end of take-off, the jumpers must reach the horizontal velocity of the centre of gravity at the moment of tread-down (u11) at level 6.81-8.48 $\mathrm{ms}^{-1}$ and not lose the horizontal velocity during take-off (u13) in range from -0.41 to $2.46 \mathrm{~ms}^{-1}$. Pole-vault female jumper should try to reach the highest approach speed and at the same time minimize its loss during take-off.

Factor u28 is explained by parameters character of take-off ( $\mathrm{u} 9-23.8 \%$ ) and angle of take-off (u53-7.1\%). This parameter is also influenced by body height of jumpers; this parameter we did not measured (fig 4, relations u28 to u9 and u53).

The watched jumpers performed a take-off in the range from $-6.5 \mathrm{~cm}$ to $34.4 \mathrm{~cm}$ (the perpendicular from the upper hand grip to the spot of take-off, and with take-off angle in the range of $67.2-83.3^{\circ}$ ). The range of activity - the operating angle ( $u 54$ ) is on $100 \%$ explained with the angle of tread-down of take-off (u52 - 47.6\%) and take-off angle (u53 - 52.4\%); see fig 4 (relations u54 to u52 and u53). We observed in our group an angle of tread-down on take-off between 63.5 and $78.8^{\circ}$ and a take-off angle in the range of $67.2-83.3^{\circ}$.

In the part of the model aimed at the activity of jumpers on pole, in the connection with the parameter $\mathrm{u} 21$, appeared indicators the loss of the horizontal speed of the centre of gravity during take-off (u13 - 20.1\%), angle between body and vertical line at moment of straightening up end phase (u56 - 17.9\%) and the moment of end of phase pull wit turn (u71 - 42.1\%); see fig 4 (relations $\mathrm{u} 21$ to $\mathrm{u} 13, \mathrm{u} 56$ and $\mathrm{u} 71$ ). The assumption of achieving the desired vertical velocity is to eliminate the loss of horizontal velocity during take-off to a level of -0.41 to $2.46 \mathrm{~m} . \mathrm{s}^{-1}$, maintain the centre of gravity of the body in the straitening up phase as close as possible to the pole $\left(4,1-48,0^{\circ}\right)$ and complete the phase pull with turn between 1,08 and $1,40 \mathrm{~s}$.

The kinematic indicator $\mathrm{u} 34$ can be explained at $90.2 \%$ with factors the height of the centre of gravity at the end of pull with turn phase (u33-29.9\%), the angle of the jumper body to the vertical at the end of pull with turn phase (u57 - 46.1\%) and the moment of end pull with turn phase (u71 - 14.2\%); see fig 4 (relations u 34 to u33, u57 and u71). From the point of view of the height of the centre of gravity at the end of the phase pull with turn that precedes the explained phase, there are appropriate values in the range of 397.8 to $446.7 \mathrm{~cm}$. At the body angle deviated from the vertical in the range of 22.9 to $70.1^{\circ}$, while the termination of this phase should be in the range of 1.08 to $1.40 \mathrm{~s}$ from the end of take-off.

In relation to $\mathrm{u} 43$, the length of the last step ( $\mathrm{u} 7 \mathrm{-11.7 \% )}$ ) and the angle of tread-down on take-off ( $\mathrm{u} 52-35.0 \%$ ) were asserted (fig 4, relations u43 to u 7 and u52). Found take-off duration we can explain with length of last step that is in our group 136.7-185.2 cm, and with angle of tread-down on take-off which values are in the range 63.5-78.8 .

Last parameter of second factor level u55 (climb angle) is explained with influence $68.2 \%$ by rate of last two steps of approach (u8), vertical velocity in the phase of hanging (u17), centre of gravity height at hanging end phase (u29) and by time duration of the same phase (u44); see fig 4 (relations u55 to u8, u17, u29 and u44). Among our female jumpers we watch shortening last step before take-off in average $9.58 \mathrm{~cm}$. Further explaining indicators are connected the phase of hanging end. Vertical centre of gravity speed should range on level 1.46-3.56 $\mathrm{ms}^{-1}$, while we 
suppose lower values. The height of centre of gravity of jumpers reached in average $128.2 \mathrm{~cm}$ and the whole phase should last $0.06-0.12 \mathrm{~s}$.

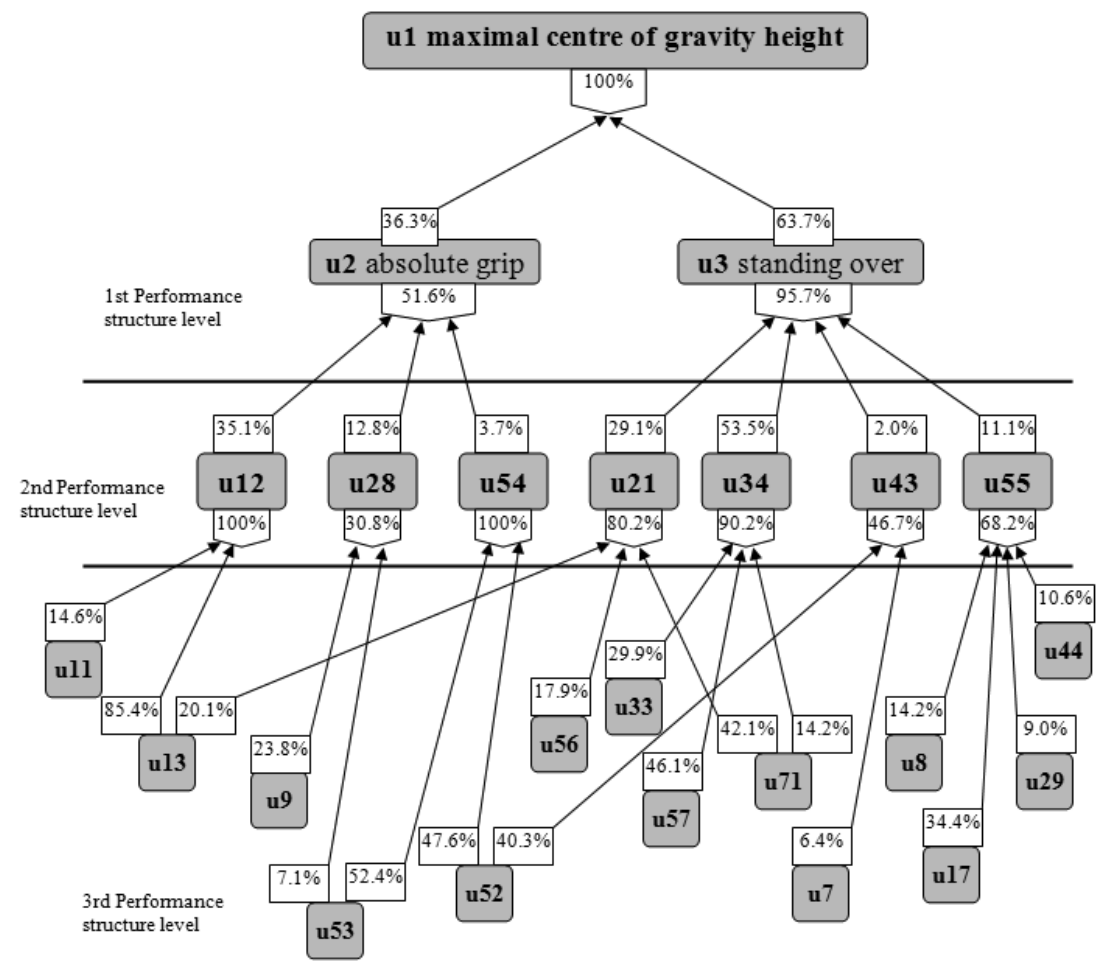

Fig. 4: Empirical model of sport performance structure in female pole-vault

\section{CONCLUSIONS}

The created empirical model of the structure of sport performance in the jump of women's jump in terms of kinematic indicators has enabled us:

- Clarify the interrelationships and conditionality of single factors not only to the sport performance but also mutually among them,

- Explain the level of technical readiness of world-class female pole-vault jumpers.

1. From the complex of technical readiness factors, the most significant influence on sport performance changes with relation to the height of absolute grip and standing over, have parameters:

- Horizontal centre of gravity speed at the end of take-off,

- Centre of gravity height at the end of take-off,

- Operating angle,

- Vertical centre of gravity speed at moment of end of phase pull with turn,

- Centre of gravity height at lifting phase,

- Time duration of take-off,

- Climb centre of gravity angle. 
2. Implementation of the indicator - the height of the center of gravity reached in the stage of lifting, and its relatively high partial influence, we consider the decisive factors influencing the sport performance as the transient individuality of the female technique.

3. The large dispersion of values, especially in the more elementary indicators of the $3^{\text {rd }}$ factor level, points to the fact that achieving this performance $(408.1-490.5 \mathrm{~cm})$ is possible to be achieved with certain individual differences. The observed fact enables to a possible further increase in sport performance.

\section{References}

BRODANI, J. 2002. Podmienenost' zmien rýchlostných a rýchlostno-silových ukazovatelov a kinematických parametrov bežeckého kroku u študentov TV v Nitre (Conditional change of speed and speed-force indicators and kinematic parameters of the run-in for students in Nitra TV). In: Sborník příspěvků mezinárodního semináře Pedagogické kinantropologie, 18-20 dubna Ostrava 2001, KTV PF OU, Ostrava 2002, str. 99-103, ISBN 80-7042-200-9.

BRODANI, J. - VAVAK, M. - SELINGER, P. 2003. Podiel' kinematických ukazovatel'ov na variabilite rýchlosti chodeckého kroku. (Share of kinematic pointers to the variability in walking speed.) In: Zborník z 2. ročníka konferencie s medzinárodnou účast'ou: Univerzitný šport a telesná výchova na začiatku III. tisícročia. KTVŠ SPU a UKF v Nitre, 6. októbra 2003, str. 177-183, ISBN 80-8069-273-4.

FRÈRE, J.' - L'HERMETTE, M. - SLAWINSKI, J. - TOURNY-CHOLLET, C. 2010. Mechanics of pole vaulting: a review. Sports Biomech. 2010 Jun;9(2):123-38. doi: 10.1080/14763141.2010.492430.

GIMUNOVA, M. - KASOVIC, M. - ZVONAR, M. - TURCINEK, P. - MATKOVIC, B. - VENTRUBA, P. - VAVACEK, M. - KNJAZ, D. 2015. Analysis of ground reaction force in gait during different phases of pregnancy. in: kinesiology. Published: DEC 2015 Volume: 47 Issue: 2 p. 236-241.

GRABNER, S. 1997. Kinematic analysis of the Women's pole vault. New studies in athletics. no. 1. IAAF 1997, s 47-61. ISSN 0971-9334.

KORVAS, P. - ZVONAR, M. - MUSIL, R. - SENKYR, J. - KALINA, T. 2013. Comparison of selected characteristics of gait in men and women. In: Journal of Human Sport and Exercise. Volume 8, Issue 2 PROC, 2013, p.114-119.

KOSTIAL, J. - DREMMELOVA, I. 2001. Štruktúra športového výkonu v atletických horizontálnych skokoch. (Structure of sport performance in athletic horizontal jumps). In: Soubor z referátů z medzinárodního semináře: Nové poznatky $v$ atletice 2000. Brno: PF MU, 2001, s. 45-49. ISBN 80-210-2640-5

KRSKA, P. 2001. Intraindividuálny efekt tréningového zat'aženia na zmeny technickej pripravenosti, pohybovej a športovej výkonnosti v skoku o žrdi žien. (Intra-individual effect of training load on changes in technical readiness, movement and sport performance in women's pole-vault jump). [Kandidátska dizertačná práca.] Banská Bystrica: FHV UMB, 2001.

KRSKA, P. - KOSTIAL, J. 2000. Štruktúra športového výkonu v skoku o žrdi žien z pohl'adu kinematických faktorov. (Structure of sport performance in the jump of women s females from the point of view of kinematic factors). In: Zborník z medzinárodnej konferencie: Atletika 2001. Banská Bystrica: FHV UMB, 2001, s. 91-100. ISBN 80-967363-1-0.

KRSKA, P. - KOSTIAL, J. - SEDLACEK, J. 2014. Determination of Angle Characteristics on Sport Performance Level in Female Pole Vault. In: Journal of Sport and Kinetic Movement, Craiova (Rumunsko), č. 23 (1)/ 2014, s. 25-28. ISSN $2286-3524$.

McGINNIS, P. M. 1997. Mechanics of pole vault take-off. In: New studies in athletics. Monaco: IAAF, 12, 1997, 1, p. $43-46$. 